U.S. DEPARTMENT OF THE INTERIOR

U.S. GEOLOGICAL SURVEY

\title{
SIX REGIONALLY EXTENSIVE UPPER-CRUSTAL SEISMIC REFRACTION PROFILES IN SOUTHWEST NEW MEXICO
}

\author{
by \\ Hans D. Ackermann', Leroy W. Pankratz, and Douglas P. Klein \\ U.S. Geological Survey, Denver, Colorado \\ Open-file Report 94-695 \\ 1994
}

This report if preliminary and has not been edited or reviewed for conformity with U.S. Geological Survey editorial standards. The use of trade, product, or firm names is for descriptive purposes only, and does not imply endorsement by the U.S. Government.

1 Retired 
Abstract $\ldots \ldots \ldots \ldots \ldots \ldots \ldots \ldots \ldots \ldots \ldots \ldots \ldots \ldots \ldots \ldots \ldots \ldots$

Introduction $\ldots \ldots \ldots \ldots \ldots \ldots \ldots \ldots \ldots \ldots \ldots \ldots \ldots \ldots \ldots$

Seismic refraction data .................... 2

Errors ................................ 3

Velocity units ........................... 4

Layer $1(1.6-3.0 \mathrm{~km} / \mathrm{sec}) \ldots \ldots \ldots \ldots \ldots \ldots . \ldots . \ldots 4$

Hydrologic implications for layer $1 \ldots . . . \ldots \ldots 5$

Layer $2(2.7-4.5 \mathrm{~km} / \mathrm{sec}) \ldots \ldots \ldots \ldots \ldots \ldots \ldots \ldots$

Layer $3(4.0-6.1 \mathrm{~km} / \mathrm{sec}) \ldots \ldots \ldots \ldots \ldots \ldots . \ldots \ldots$

Acknowledgements $\ldots \ldots \ldots \ldots \ldots \ldots \ldots \ldots \ldots \ldots \ldots \ldots \ldots \ldots$

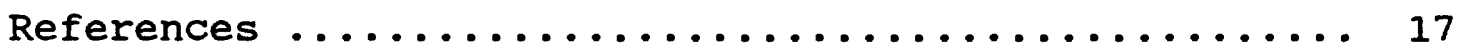

\section{ILLUSTRATIONS}

Figure 1 - Location of seismic refraction lines in southwest New Mexico. .............. 7

Figure 2 - Velocity section for line 1......... 8

Figure 3 - Velocity section for line 2......... 9

Figure 4 - Velocity section for line 3.......... 10

Figure 5 - Velocity section for line 4......... 11

Figure 6 - Velocity section for line 5......... 14

Figure 7 - Velocity section for line $7 \ldots \ldots \ldots$

Plate I - Map showing shotpoint locations 


\title{
SIX REGIONALLY EXTENSIVE UPPER-CRUSTAL SEISMIC REFRACTION PROFILES IN SOUTHWEST NEW MEXICO
}

\author{
by \\ Hans D. Ackermann, Leroy W. Pankratz, and Douglas P. Klein \\ U.S. Geological Survey, Denver, Colorado
}

\begin{abstract}
$\underline{\text { ABSTRACT }}$
This report presents 790 kilometers of seismic refraction velocity sections in southwest New Mexico. Velocity structure is depicted to about $2.5 \mathrm{~km}$ depth. Seismic data were processed by the United states Geological survey (USGS) from industryacquired, reversed seismic-refraction lines using shotpoints spaced at $3.2 \mathrm{~km}$, and grouped geophones at $201 \mathrm{~m}$ spacing. The data are on six profiles located in the region from the Mexican border northward to about $32^{\circ} 30^{\prime} \mathrm{N}$, and from the Arizona-New Mexico border eastward to the Rio Grande river. Geologic interpretation is not part of this report, however, the generalized lithology of the principal velocity units is inferred. Beneath a surface layer $(0.85 \mathrm{~km} / \mathrm{sec})$ composed of dry, unconsolidated material, the seismic units consist of: 1) a 1.6 $3.0 \mathrm{~km} / \mathrm{sec}$ zone believed to indicate mostly Quaternary basin fill, 2) a $2.7-4.5 \mathrm{~km} / \mathrm{sec}$ zone that is probably Tertiary sedimentary and volcanic rock for the most part, with possible local masses of Paleozoic sedimentary rock, and 3) a 4.0 to $6.1 \mathrm{~km} / \mathrm{sec}$ (locally near $7.0 \mathrm{~km} / \mathrm{sec}$ ) zone inferred to represent dense, low-porosity, crystalline rock.
\end{abstract}




\title{
SIX REGIONALLY EXTENSIVE UPPER-CRUSTAL SEISMIC REFRACTION
}

\section{PROFILES IN SOUTHWEST NEW MEXICO}

\author{
by
}

Hans D. Ackermann, Leroy W. Pankratz, and Douglas P. Klein U.S. Geological Survey, Denver, Colorado

\section{Introduction}

During the summer of 1980 the Branch of Regional Geophysics (now Branch of Geophysics) of the U.S. Geological Survey (USGS) was asked by the Water Resources Division (WRD) of the USGS to interpret approximately $800 \mathrm{~km}$ of seismic refraction data which was originally acquired and interpreted by Geophysical service, Inc. (GSI) in July 1969. Results of the interpretation, although provided to WRD, have never been published. Two authors (H.A. and L.P.) left the Branch of Geophysics soon after this work was completed. Interest in the data has revived as a result of a recent request to the USGS from the Bureau of Land Management to provide a resource and environmental assessment of southwest New Mexico. It is under the auspices of this latter work that the present report was prepared.

Figure 1 shows the location of the seismic refraction lines. The lines are designated $1,2,3,4,5$, and 7 ; there is no line 6. The survey covers a broad swath of the southwest Basin and Range Province extending from the Arizona border eastward to the Rio Grande River, and from the Mexican border to about lat. $32^{\circ}$ $30^{\prime} \mathrm{N}$. Three lines $(1,3$, and 7) traverse the axis of basins in roughly north-south directions; the remaining three lines (2, 4, and 5) cut across various ranges and basins along east-west directions.

Although the initial use of these data was to study water resources, the data contain information on structure and lithology that can be applied to other Earth studies. Examples include locating intrusions, fracture zone, and elevated bedrock as potential targets for mineral exploration, and definition of upper-crustal velocity structure to aid in processing and interpretation of long-offset, regional, deep-crustal refraction and reflection seismic data. We know of no similarly detailed upper-crustal refraction data for this area that are available to the public, although several deep-crustal refraction lines bear on the regional tectonic setting. Braile and others (1989) provide a review of the deep-crustal studies; sinno and others (1986) present several lines that cross the present area. Data presented by Sinno and others (1986) define the velocity structure in the depth range of about 3 to $30 \mathrm{~km}$; although this is relevant to the broad tectonic picture, their results provide 
little information for the shallower depth range of the present data.

\section{Seismic refraction data}

Data were acquired using a Texas Instrument's 48-trace digital field system. The principal facts of data acquisition are tabulated below:

- Nominal shot-point interval: $3.2 \mathrm{~km}$

- Charges: $68-91 \mathrm{~kg}$

- Shot-hole depth: $24-38 \mathrm{~m}$

- Two shots with backward and forward geophone spreads

- Off-end shooting with near-trace at $50 \mathrm{~m}$

- Grouped geophones at intervals of $201 \mathrm{~m}$

- Three $4.5 \mathrm{~Hz}$ geophones clustered to each recording group

- Gain set at straight gain mode

- Filters - high-pass: $37.5 \mathrm{~Hz}$ (low-pass out)

- Line, shotpoint and geophone maps scale: 1;12,000

To analyze the refracting horizons, analog records were picked for first breaks in arrival times; record quality ranged from poor to very good. Traverse lines with labeled shotpoints on original maps having a scale of 1:12,000, were replotted by hand to a scale of 1:250,000. The replotted shotpoint locations are estimated to be accurate to within about $300 \mathrm{~m}$. For the present report, a photographically reduced version of the 1:250,000 map composite is presented as plate I at a scale of about 1:635,000.

Data were processed and analyzed based on a set of interactive computer programs (Ackermann and others, 1982, 1983). Reversed travel-time curves for each individual layer were constructed from the plotted travel-time points (Ackermann and others, 1986). The programs derive a model which computes thickness and velocity variations within each layer which satisfy the travel-time curves. The model assumes that velocity increases vertically downward. A forward modeling program is then invoked which computes an accurate theoretical travel-time curve for each layer of the derived model which is then compared against the initial data to verify the results. In order to secure a better fit, or to test an alternate model, changes are occasionally made in the derived model and the forward program run again.

A surface layer of variable thickness (seldom more than 150 $\mathrm{m}$ ) and constant velocity of $0.85 \mathrm{~km} / \mathrm{sec}$ was incorporated into all velocity sections. This layer was required to account for dry, porous, and unconsolidated rock or soil. The assigned velocity is considered typical of surface material in the region. This layer is too thin to be reliably identified on the plotted 
travel-time points because of the $200 \mathrm{~m}$ geophone spacing, thus the data provide poor constraints on it's velocity.

Resulting velocity sections for the present work are shown on figures $2-7$ in metric units with velocity in $\mathrm{km} / \mathrm{sec}$. Horizontal variations in velocity are interpreted in blocks, typically 4 to $10 \mathrm{~km}$ in length. Bounds of the blocks are indicated on the sections by horizontal to dipping lines defining the refracting horizons, and short vertical lines between refracting horizons. Velocity within a block is representative of the average velocity spanning the block. Where velocities changes are uncertain, dashed lines are drawn.

Seismic lines were segmented for processing convenience and were labeled (A,B, or East, West, etc.), as shown on the figures $2-7$ and on plate $I$. The shotpoint numbering system here is different from that used in original data acquisition. Shotpoints for each segment begin at number 1 (see plate I). Each shotpoint has two consecutive numbers that code two shots at each location, one for recording in the forward direction from the shotpoint, the other for recording in the reverse direction. Where segments overlap, shotpoints have an additional number (or pair of numbers) representing the adjacent segment. only one of the numbers for each shotpoint is shown on the sections (figs. 2 - 7), but the full shotpoint coding is shown on plate I. Not all shotpoints are shown on the sections, but these deletions can be interpolated by inspection of plate $I$.

\section{Errors}

A singular solution is not inherent from seismic refraction data due to hidden layers (layers without clear travel-time segments) and velocity reversals. We present no estimates on the bounds for likely variability in either physically or geologically acceptable alternate solutions. Information from borehole lithologic or sonic logs could be used to contrain models of this type or to confirm the accuracy of the models but that was not done here.

An analysis of errors in shallow seismic refraction results by Eaton (in Zohdy and others, 1974, p.77-78) is relevant to errors in the present data. Eaton described a comparison of 97 seismic refraction depth determinations with drill-hole depths. The depth determinations were all under $100 \mathrm{~m}$ in that study. The results showed that about 95-percent of data showed errors in depth determinations of 20-percent or less, and about 5-percent of the data showed errors of 30- to 90-percent in depth determination. Eaton (in Zohdy and others, 1974) noted that the larger errors always overestimated the depth; this was inferred to be because of unrecognized velocity reversals. These results, and experience, has shown, that solutions like those presented 
here are reasonably accurate and can be integrated with geology and well logs with minor adjustments.

Internal consistency in the seismic interpretation can be evaluated by inspecting the discrepancies at traverse intersections inasmuch as all lines were processed independently. There are insufficient data to provide statistical estimates of error, but qualitative comparisons are useful. Five of the seven intersections are at locations where the velocity sections were well enough developed on both of the intersection lines to provide comparative data (intersections of 1 ines 1 and 4 , Iines 1 and 5,1 ines 2 and 3,1 ines 3 and 4,1 ines 4 and 7, and 1 ines 5 and 7. On the average, layer depths are consistent within about $50 \mathrm{~m}$ (close a 20-percent discrepancy), and velocity values correspond to within about $0.2 \mathrm{~km} / \mathrm{sec}$.

\section{Velocity units}

Acoustic velocities (Vp) in the sections presented here can usually be assigned lithologic significance using rock-velocity relationships (Diment, 1980; Christianson, 1989) combined with local geology and drill hole information (Thompson, 1977, 1981; Thompson and others, 1978; Gates and others, 1978; Zeller, 1965). The sections show that the interpreted layers often dip, are discontinuous, and show significant variable velocity. This lateral structure shows where bedrock and basement may be faulted or intruded, or where there is a possible change in the facies of sedimentary lithology.

Geological interpretation of the velocity sections is not our aim. However, we will outline the major vertical zonation seen in the profiles and suggest the likely range of lithology that the velocities may represent.

The sections show velocity variations ranging from about 2 to $6 \mathrm{~km} / \mathrm{sec}$. The various blocks resulting from the seismic interpretation show 3 to 5 layers (with lateral changes in velocity within a layer being less than vertical changes in velocity across layers). For the present description the 2 or 3 mid-level layers are merged into a single zone and we consider three significant zones numbered downward from below the uppermost layer (a layer with assigned velocity of $0.85 \mathrm{~km} / \mathrm{sec}$ representing the dry, loose, weathered, near surface materials).

Layer 1 ( 1.6 to $3.0 \mathrm{~km} / \mathrm{sec})$ : This layer, starting at about 50 to $150 \mathrm{~m}$ depth beneath the surficial zone and pinching out in mountain ranges, is believed to be a porous zone of unconsolidated to poorly consolidated gravel, alluvium, sand, clay and possibly thin layers of volcanic rock. The material is probably Quaternary age for the most part. Where velocities are 
about 1.8 or greater, the layer is probably water saturated. The layer varies considerably in thickness, even in the central parts of basins. The thickness of this layer commonly ranges between $150 \mathrm{~m}$ to $400 \mathrm{~m}$ but reaches about $700 \mathrm{~m}$ at 4 locations: 1) part of the Playas Valley on line 2 (fig. 3, east of the intersection with line 1); 2) Hachita Valley on line 4 (fig. 5; near the overlap of sections $4 \mathrm{~A}$ and $4 \mathrm{~B}) ; 3$ ) West side of Animas valley on line 5 (Fig. 6, section 5A); and 4) Deming Basin on line 5 (Fig. 6, section 5B), and line 6 (Fig. 7, section 7B).

Hydrologic implications for layer 1: Near the town of Picacho in southern Arizona, comparison of drill hole data and detailed seismic refraction models (based on 15-m geophone spacing) showed that the top of the water saturated zone correlates well with the top of 1.9 to $2.0 \mathrm{~km}$ basin material (Pankratz and others, 1978). Water can probably be extracted from rocks and loose material when porosity exceeds about 20percent; this is where compressional velocity in unconsolidated sediments is less than about $3.0 \mathrm{~km} / \mathrm{sec}$ (Eaton, in Zohdy and others, 1974, figure 63, p.83). Thus, shallow basin aquifers are likely where velocity in layer 1 ranges from about 2 to $3 \mathrm{~km} \backslash \mathrm{sec}$.

Layer $2(2.7$ to $4.5 \mathrm{~km} / \mathrm{sec})$ : The velocity sections show two or three discrete layers between layer 1 and the deepest layer detected. These intermediate layers show velocity differences of about $0.6 \mathrm{~km} / \mathrm{sec}$, which is believed significant and resolvable. However, without detailed drill-hole correlations we prefer not to infer lithologic significance to each of these layers. For this report, the intermediate layers are grouped as layer 2. The velocity range in this layer probably encompasses many rocks, but volumetrically layer 2 most likely consists predominantly of Tertiary clastic and volcanic rock. Where seismic units have velocity values approaching $4 \mathrm{~km} / \mathrm{sec}$ in this layer, the units are more highly cemented or indurated or welded (for volcanic rocks) than at lower velocities. It is unlikely that competent crystalline rock such as limestone, dolomite, metamorphic rock, or igneous intrusions make a major contribution to the rocks in this layer. Units having the lower velocities, near $3 \mathrm{~km} / \mathrm{sec}$, may have sufficient porosity to form deep aquifers.

Layer 3 (4.0 to $6.1 \mathrm{~km} / \mathrm{sec})$ : This is the deepest refracting horizon detected and forms the core of mountain ranges as well as the floor of basins. The layer is composed chiefly of rock with velocities in the range of 4.0 to $5.1 \mathrm{~km} / \mathrm{sec}$. This range of velocities most likely reflects intrusions, strongly welded volcanic rock, carbonate and siliceous-cemented sedimentary rock, and metamorphic rock. Units with velocities exceeding $5 \mathrm{~km} / \mathrm{sec}$ probably represent lower fracture densities and higher mafic composition (in igneous or metamorphic rock) than units with lower velocities. In places where this layer is shallow below valleys, uplifts or intrusions may be present that may present barriers to ground water flow and may point out possible targets 
for mineralized rock. There are also a few localities where layer 3 is undetected, which may suggest that these places have been disturbed by volcanic centers, or may have unusually thick Tertiary sedimentary and volcanic rock layers.

\section{Acknowledgements}

This work was possible from data and funding provided through Dave Wilkins of the Albuquerque, New Mexico office of the water Resources Division (WRD), USGS. Chuck Heywood (WRD, Albuquerque) and Virginia McLemore (NM Bureau of Mines and Mineral Resources, Socorro) were helpful in providing sources of drill-hole information for the area. Jackie williams, Branch of Geophysics, USGS, Denver, assisted in the data processing, and in the initial graphical work on the sections shown. Pat Hill, also of the Branch of Geophysics, Denver, contributed to the graphical work on the sections. 


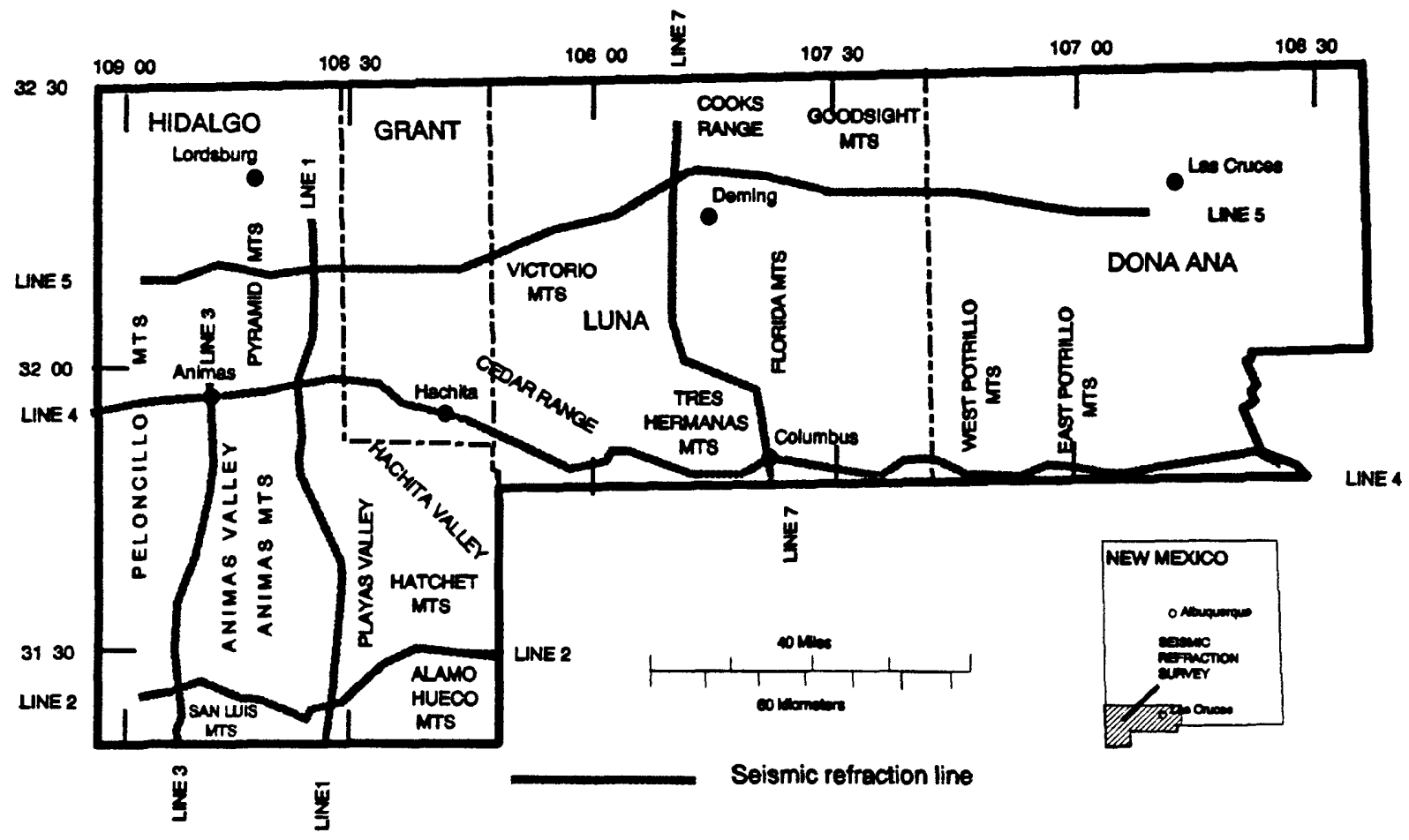

Figure 1-Location of seismic refraction lines in southwest New Mexico. 


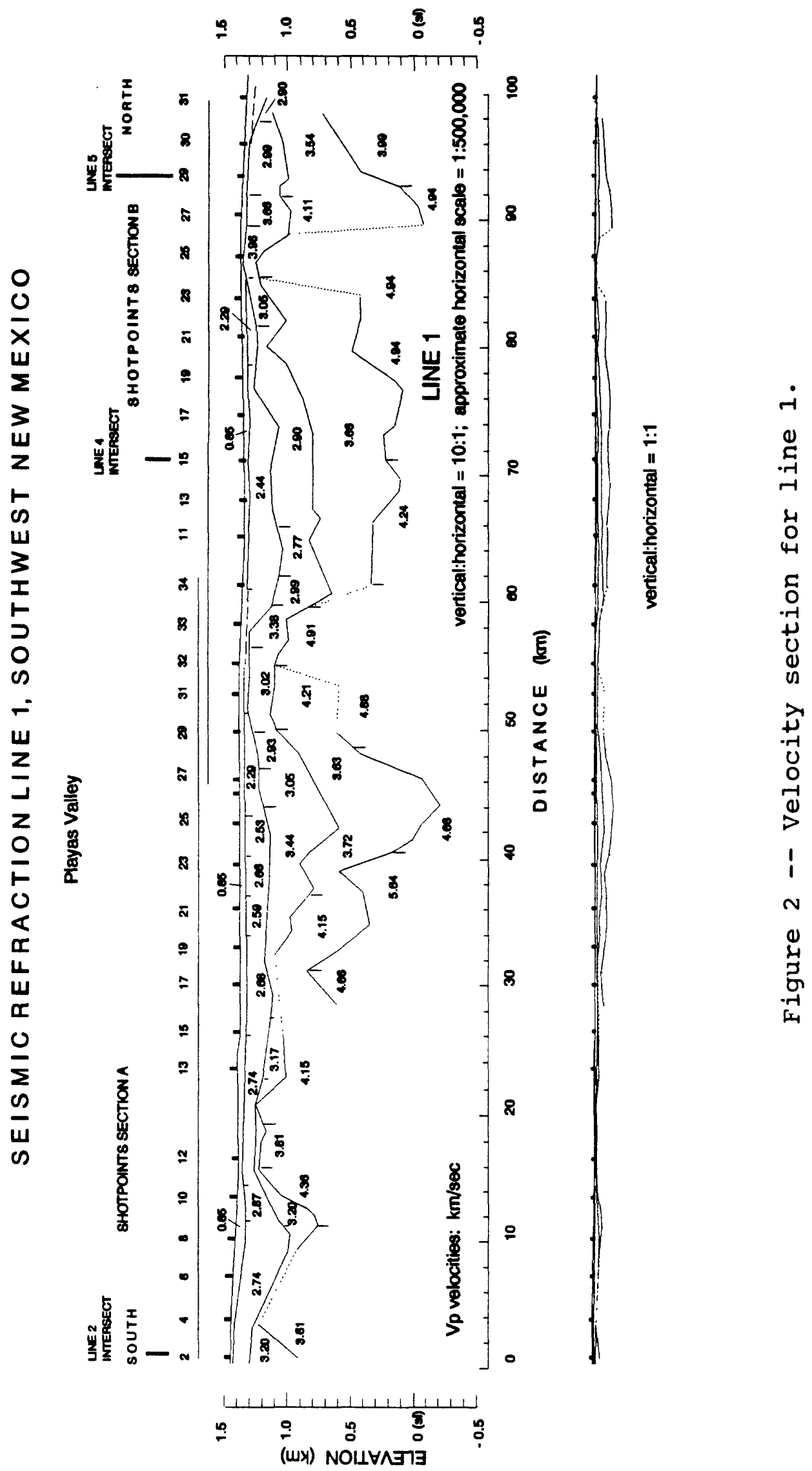




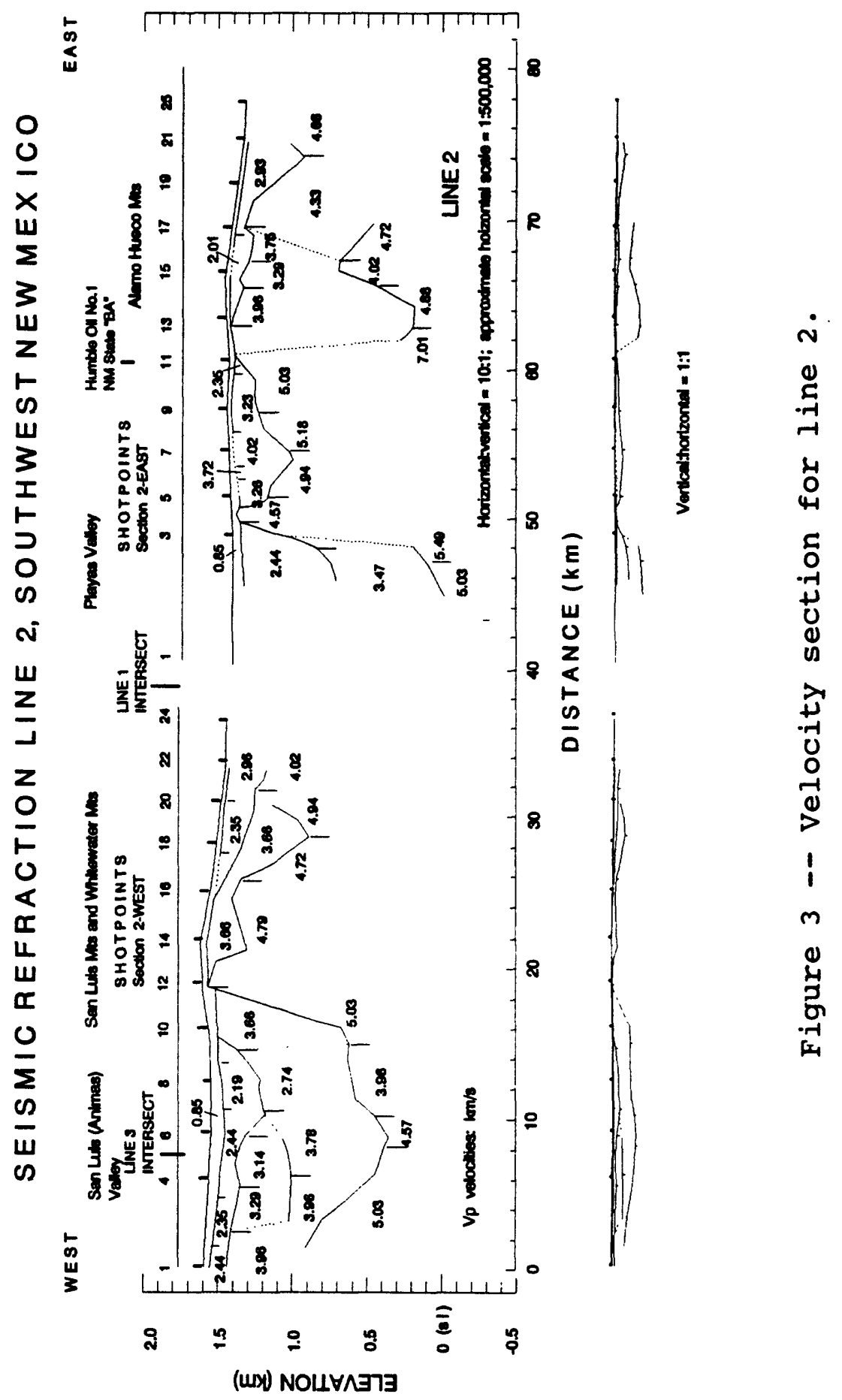




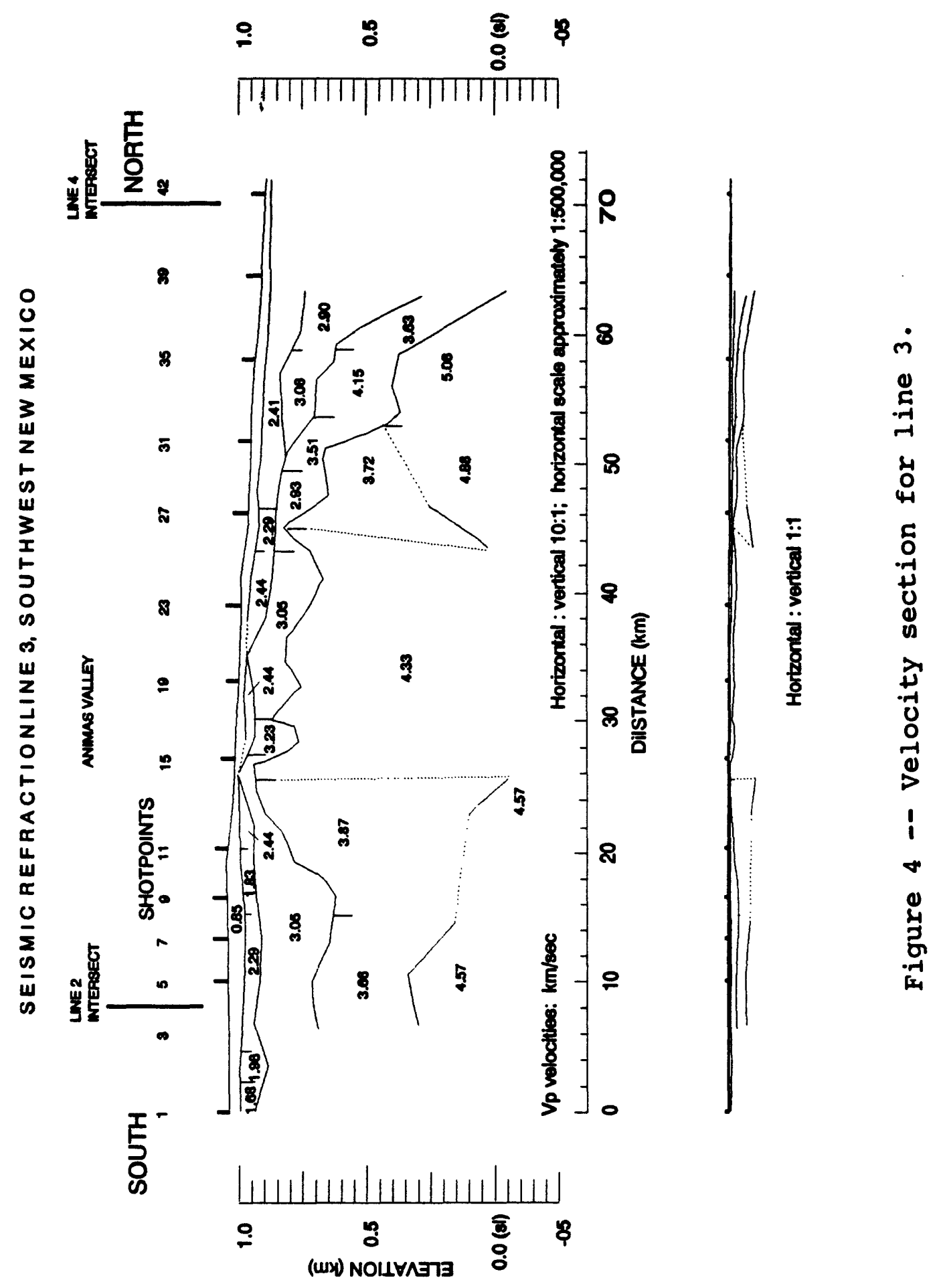



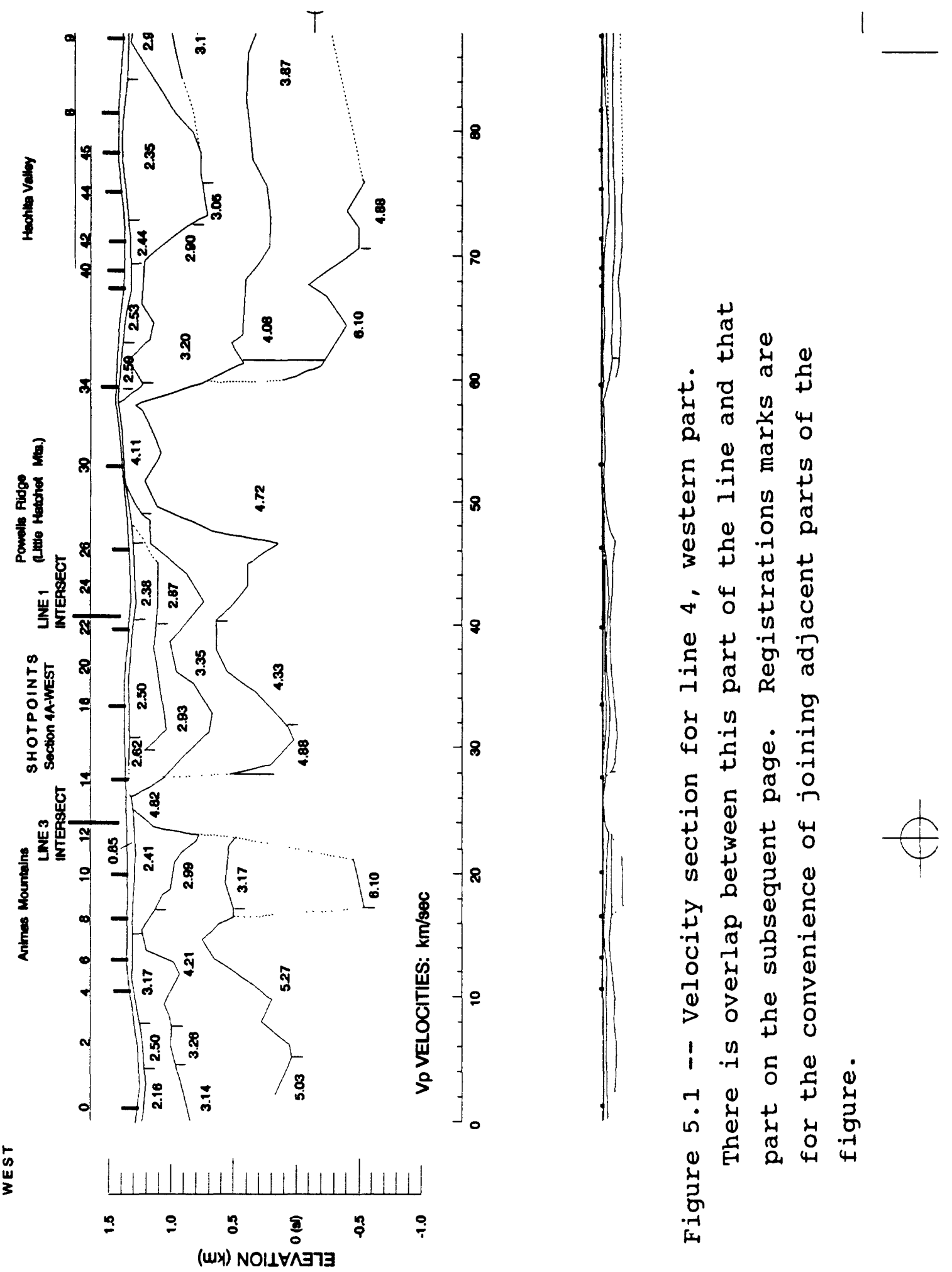
$\phi$

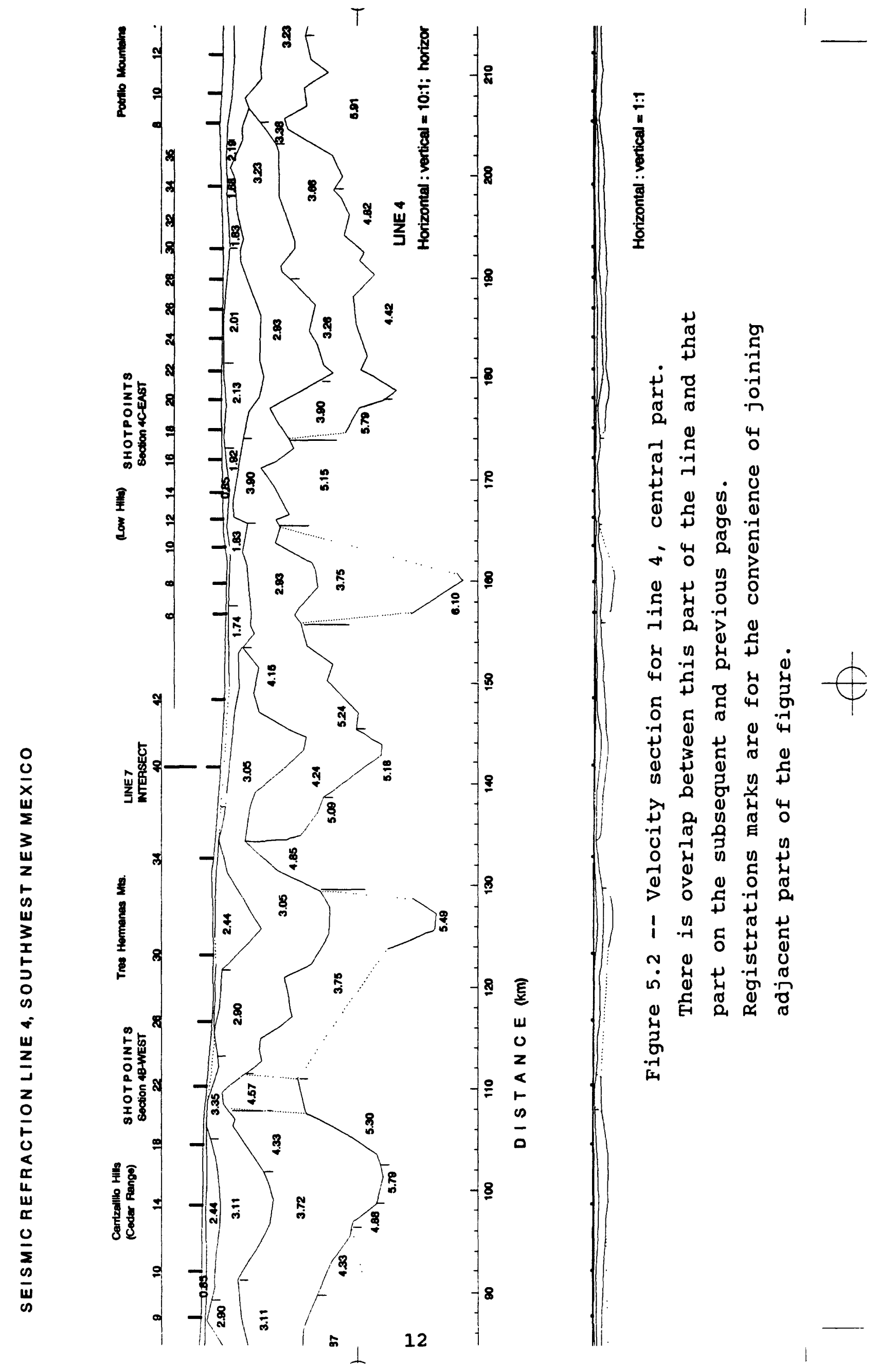




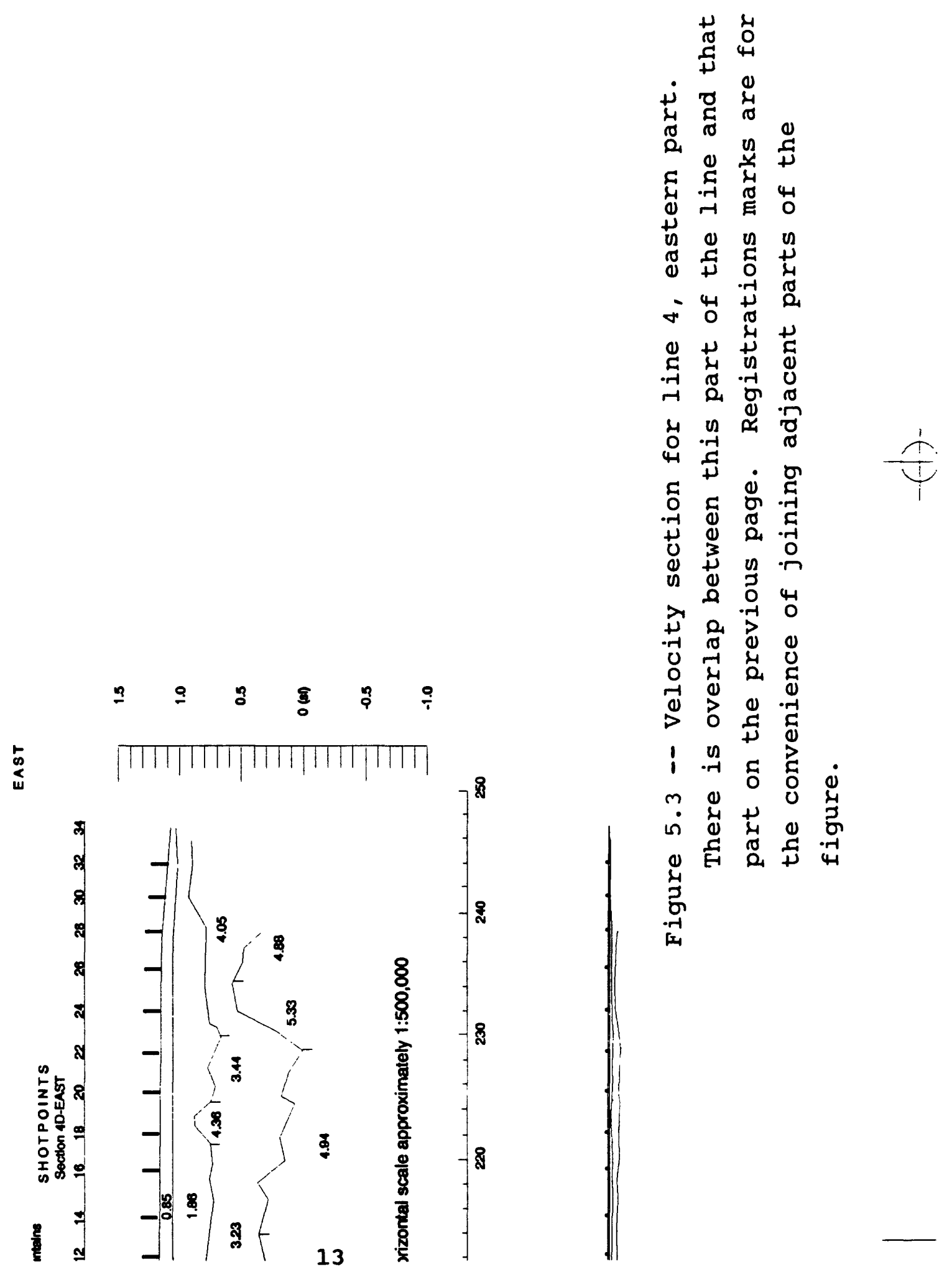




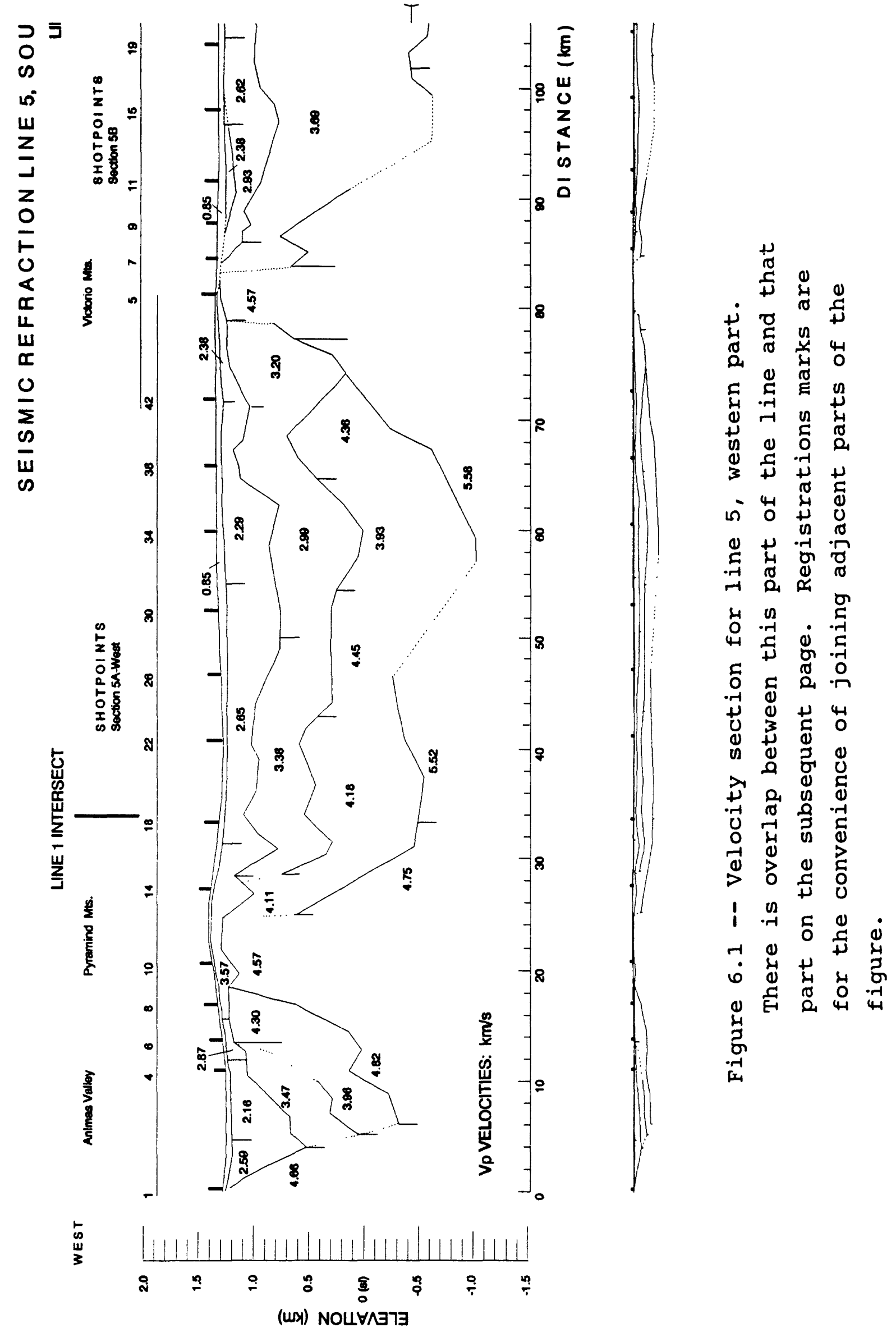




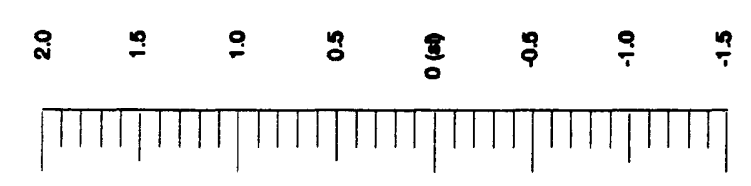

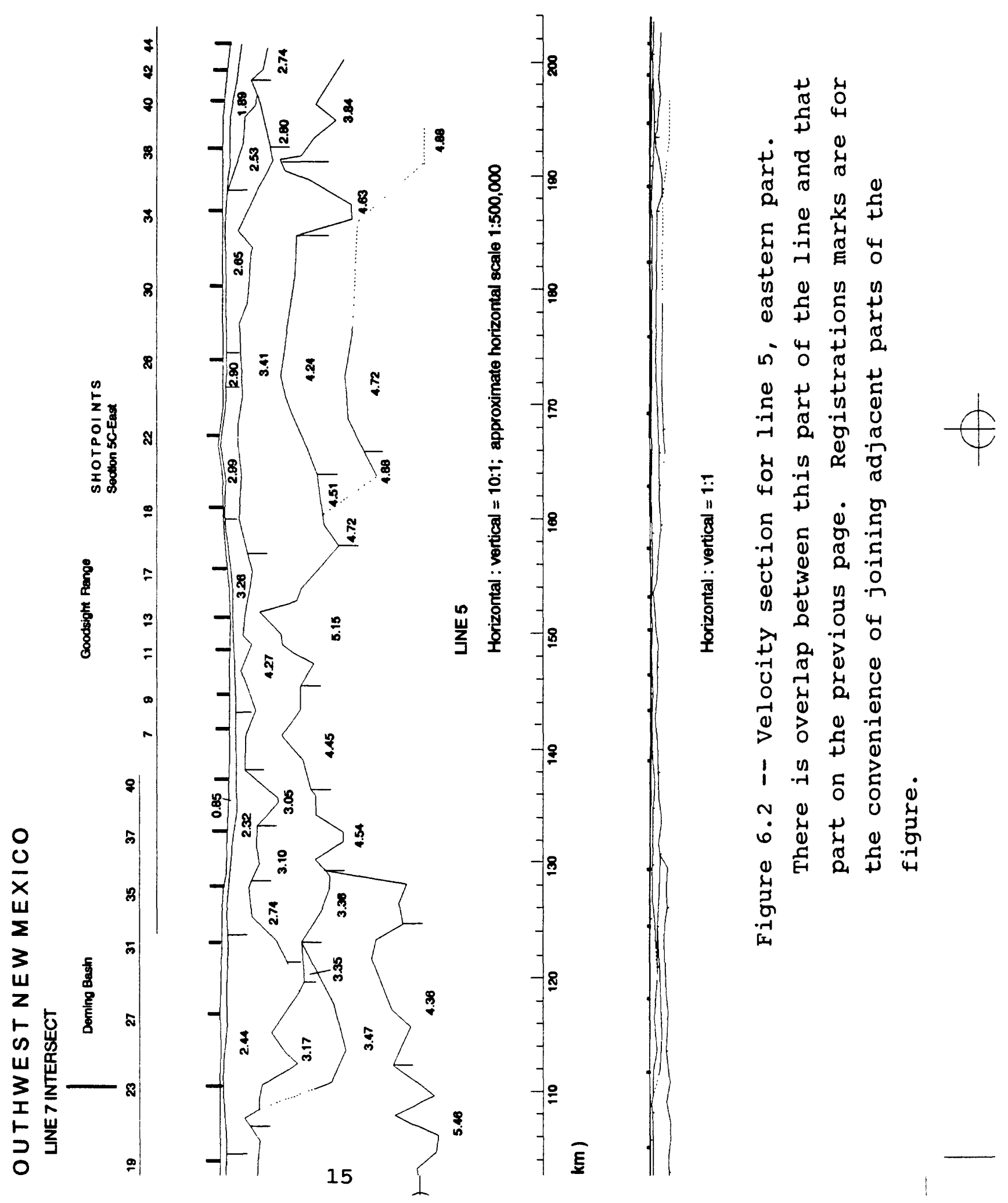




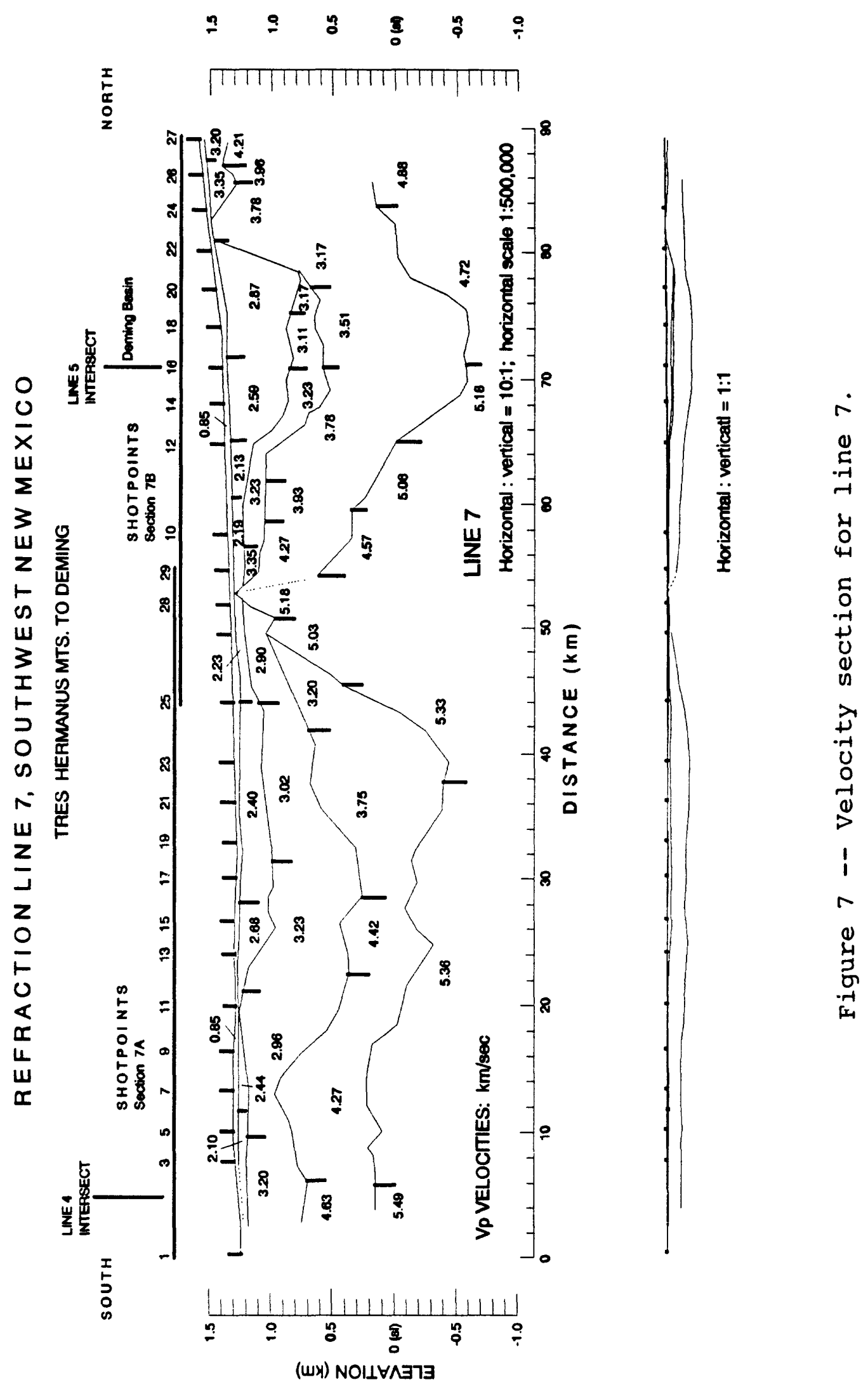




\section{References}

Ackermann, H.D., Pankratz, L.W., and Dansereau, D.A., 1982, A comprehensive system for interpreting seismic-refraction arrival time data using interactive computer methods: United States Geological Survey, Open-File Report 82-1065, 265 p.

Ackermann, H.D., Pankratz, L.W., and Dansereau, D.A., 1983, Computer program modifications of open-File Report 82-1065; a comprehensive system for interpreting seismic-refraction arrival-time data using interactive computer methods: United States Geological Survey Open-File Report 83-604, 2 p.

Ackermann, H.D., Pankratz, L.W., and Dansereau, D.A., 1986, Resolution of ambiguities of seismic refraction traveltime curves. Geophysics, v.51, no.2, p.223-235.

Braile, L.W., Hinze, W.J., von Frese, R.R.B., Keller, G.R., 1989, Seismic properties of the crust and uppermost mantle of the conterminous United States and adjacent Canada: Geological Society America Memoir 172, p.655-680.

Christianson, N.I., 1989, Seismic velocities, in Charmichael,R.S., CRC practical handbook of physical properties of rocks and minerals: Boca Raton, Florida, CRC Press, p. 429-546.

Diment, W.H., 1980, Resource characteristics: exploration evaluation and development, in Kestin, Joseph, DiPippo, Ronald, and Ryley,D.J., eds., sourcebook on the production of electricity from geothermal energy: Washington D.C., U.S. Government Printing office, p. 1-103.

Gates, J.S., White, D.E., Stanley, w.D., and Ackermann, Hans D., 1978, Availability of fresh and slightly saline ground in the basins of westernmost Texas. U.S. Geological Survey Open-File Report 78-663.

Pankratz, L.W., Ackermann, H.D., and Jachens, R.C., 1978, Results and interpretation of geophysical studies near the Picacho fault, south-central Arizona. U.S. Geological Survey openFile Report 78-933, $17 \mathrm{p}$. 
Sinno, Y.A., Daggett, P.H., Keller, G.R., Morgan, P., Harder, S.H., 1986, Crustal structure of the southern Rio Grande Rift determined from seismic refraction profiling. Journal Geophysical Research, v.91, no. B6, p. 6143-6156.

Thompson, Sam, III, 1977, Geology, petroleum source rocks, and thermal metamorphism in KCM No.1 Forest Federal well, Hidalgo Country, New Mexico: New Mexico Bureau Mines and Mineral Resources Circular 152, 62 p.

Thompson, Sam, III, 1981, Petroleum source rocks in exploration wells drilled to Paleozoic or Mesozoic units, Hidalgo and Grant Co., New Mexico. New Mexico Bureau Mines and Mineral Resources, Open-File Report 153, 126 p.

Thompson, Sam, III, Tover, J.C., and Conley, J.N., 1978, Oil and gas exploration wells in the Pedrogosa basin; in Callender, J.F., Wilt, J.C., and Clemons, R.E., eds., New Mexico Geological Society, 29th Field Conference Guidebook, p. 331344 .

Zeller, R.A., Jr., 1965, stratigraphy of the Big Hatchet Mountains Area, New Mexico. Socorro, State Bureau of Mines and Mineral Resources, New Mexico Institute of Mining and Technology Memoir 16, $125 \mathrm{p}$.

Zohdy, A.A., Eaton, G.P., Mabey, D.R., 1974, Application of surface geophysics to ground-water investigations, U.S. Geological Survey, Techniques of Water-Resources Investigations of the United States Geological survey, TWI02-D1 (reprinted 1990), $116 \mathrm{p}$. 